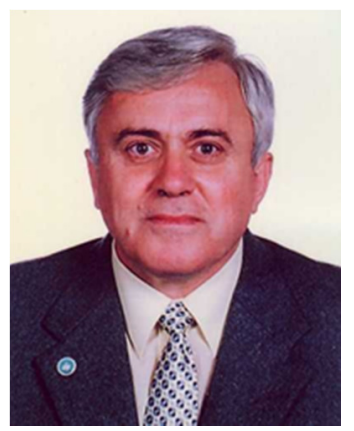

\title{
Győri Zoltán 70 éves
}

Győri Zoltánt a Debreceni Egyetem professzorát 70. születésnapja alkalmából tiszteletteljes nagyrabecsüléssel köszönti a hazai és nemzetközi talajtani agrokémiai - élelmiszeranalitikai szakembertársadalom, munkatársainak, tanítványainak és követőinek széles tábora. Egy születésnapi köszöntés nem lehet a professzor úr hihetetlenül gazdag életmüve eddigi szakaszának teljességre törekvő bemutatása, még akkor sem, ha ehhez több évtizedes szakmai és baráti együttmüködésünk forrásait is fel tudtam használni. Ezen mérföldkövek mentén végzett összegzés egyaránt fontos visszatekintést jelent nem csak az egyénnek, hanem a szélesebb szakmai közösségnek is.

Győri Zoltán 1948. szeptember 22. született Tiszaföldváron. A folyó szeretete már ifjúkorában beleívódott gondolkodásába és szakmai előmenetele során is sokszor felbukkant akár annak szépségéről vagy - a cianid szennyezés kapcsán annak megmentéséről volt szó. Gimnáziumi tanulmányait, majd érettségi vizsgáit Mezötúron tette le. Szülöi környezete és kiváló tanárai hamar felfedezték a kémia iránti korai vonzalmát, így egyenes út vezetett pályaválasztásához.

Egyetemi tanulmányait 1973-ban az akkori KLTE TTK-án okleveles vegyészként fejezte be. Pályája kezdetén közvetlenül kapcsolódott az akkori, Bocz professzor fémjelezte kutatási területekhez. 1974-1989 között a DATE Növénytermesztési Tanszék tanszéki mérnöke, tudományos segédmunkatársa majd, tudományos munkatársa. Pályája korai szakaszát jelzi, hogy 1978-ban környezetvédelmi szakmérnöki diplomát (VVE), majd 1988-ban mezőgazdasági tudomány kandidátusa (MTA) fokozatot, míg 1995-ben habilitált doktori címet szerzett (DATE).

Kutatási témáit 1974-től a növénytáplálással és a minőséggel kapcsolatos vizsgálatok köré építette. Már ekkor nagyon széleskörü és gyümölcsözö együttmüködést alakított ki a hazai agrár-felsőoktatási intézmények kutatóival, oktatóival. Ezek a kapcsolatok akkor teljesedtek ki, amikor a DATE MTK-n a Regionális Agrár Müszerközpontot megszervezte és annak vezetőjeként 1986-tól 2010-ig nagyon intenzív tudományszervezői feladatot végzett. Ez az időszak, amiben kutatói mentalitása kiteljesedhetett. 2000-ben megítélik számára az MTA 
doktora címet „A termesztési tényezők hatása egyes gabonafélék és maghüvelyesek minőségére" címü értekezése alapján.

A Debreceni Egyetem AGTC-n (korábban DATE-n) elöbb a minőségvizsgálati, később az élelmiszertudományi oktatás meghonosítója, e területen mind az oktatásban, mind a kutatásban iskolateremtő tevékenységet folytatott.

Az általa vezetett müszerközpontban munkatársaival számos olyan területtel napi szinten foglalkozott és már akkor a „szántóföldtől az asztalig” terjedő vizsgálati láncot működtetett, ami csak évtizedek múlva jelent meg az EU kutatási föirányában. Ez a tevékenysége sok területen olyan úttörő munkát kívánt meg, amely professzor úr kitartó szorgalma és óriási tudásvágya nélkül nem valósulhatott volna meg. Sikeres módszer- és termékfejlesztési tevékenységet is folytatott (elemtartalom, tésztareológia, talajkivonó szerek alkalmazása). Gyakorlati tevékenységét 10 szabadalom (termék és eljárás) mellett a versenyszférával együtt folytatott nagyon sikeres pályázati tevékenysége fémjelzi. Ezek közül a meghatározóak: az infrastruktúrafejlesztési pályázatok: öt OTKA, két MKM, három FM és KÖM, 2 NKFP, 3 GVOP, valamint 1 KTIA pályázat. Nemzetközi kutatási pályázatokban NATO, NSF, és 3 (FP6, FP7, COST) EU-projekt témavezetöje. Továbbá kétoldalú TÉT együttmüködések résztvevője francia, horvát és görög partnerekkel, illetve multilaterális (GRESO) együttműködés hazai koordinátora. A Proland (Pulawy) kiválósági központ Tanácsadó Testületének tagja 2002-2005 között. Egy TEMPUS projektben (2005-2008) pedig élelmiszer tudományi tananyagfejlesztésben vett részt a Zágrábi Egyetemen.

Az elmúlt években - a nagyszámú az élelmiszerbiztonság szempontjából fontos mérési illetve kísérleti adat (talaj, növény, takarmány, élelmiszer-alapanyag, nehézfém, növényvédőszer-maradvány, mikotoxin) birtokában, ez a szakterület munkájában mind nagyobb hangsúlyt kapott. A társintézmények képviselőivel a sikeres együttműködés az elmúlt évtizedben az élelmiszerbiztonságot szolgáló minőségirányítási területen is megvalósult. Ezekben a kutatási témákban a talaj-növény-állat-ember tápláléklánc kutatásával foglalkozott, ahol új eredményeket ért el az egyes növényi termékek táplálóanyag és elemtartalmával, különösen a toxikus vagy potenciálisan toxikus elemekkel. Kutatásai kiterjedtek a talajtermékenységet befolyásoló anyagok/vegyületek (szerves- és mütrágyák, levéltrágyák, ipari melléktermékek) hatásának vizsgálatára, valamint egyes növényi termék-feldolgozási technológia pontosítására is.

Professzor úr és munkatársai a világ számos országának nemzetközi és hazai rendezvényén mutatták be és meghatározó nemzetközi tudományos folyóiratokban közölték eredményeiket. Jelentősebb tudományos közéleti szereplését jelzi, hogy 1993-tól SETAC EUROPE (Society of Environmental Chemistry and Toxicology), az AACC (American Association of Cereal Chemists, 1995-töl CIEC Magyar Nemzeti Bizottság, 2008-tól EU COST Food and Agricultural Domain Committee tagja. 2014-től elnöke az MTA Elnöki Környezet és Egészség Bizottság Élelmiszerbiztonsági Albizottságának, illetve 2018-tól a Hungarikum Bizottság Agrár- és Élelmiszergazdasági Szakbizottságának. Elismertségét mutatja, hogy több jelentős visszhangot kiváltó USAMV (2001), Flour-Bread (2005), ISSPA (2007), 
IAMA (2009), Food Structure Design (2018) konferencia szervezője. Több hazai és külföldi folyóirat (így az Agrokémia és Talajtan) szerkesztője és rendszeres bírálója is. Hazai és nemzetközi publikációs tevékenységét jelzi 566 tudományos közleménye, 8 könyve és 32 könyvfejezete, amelyekre 1636 független hivatkozást kapott.

Győri professzor úr nemcsak kutatóként, hanem oktatóként is jelentős eredményeket tudhat magáénak: A Táplálkozástudományi Intézet egyetemi tanára, a DE ATC Minőségbiztosítási és Mikrobiológiai Intézetének vezetője (2007-2011), tudományos dékánhelyettes (1991 - 1994), tudományos rektorhelyettes (1998-2000), Universitas elnök, kutatóintézeti föigazgató.

Életpályája során vezetőként hozzájárult vezetett intézménye fejlődéséhez, hírnevének öregbítéséhez. Elhivatottsággal kutatott, oktatott több mint 40 évet a Debreceni Egyetemen. Nemcsak a kutatás területén vállalt fel bátran a környezetében új területeket, hanem az oktatásban is. A professzor úrnál az előadók mindig telve voltak és az alapoktól épített fel máig nagyon népszerü új szakokat. Tanítványainak mindig nagy lelkesedéssel adta át a folyamatosan naprakész legújabb ismereteit.

A Debreceni Egyetem AGTC-n előbb a minőségvizsgálati, később az élelmiszertudományi oktatás meghonosítója. E területen mind az oktatásban, mind a kutatásban iskolateremtő tevékenységet végzett. A Mezőgazdasági Termékfeldolgozás és Minősítés szakirány beindítása után, szakvezetője volt az Élelmiszermérnöki BSc, az Élelmiszerbiztonsági és -minőségi mérnöki MSc, korábban pedig az Élelmiszer minőségbiztosító agrármérnök, Minőségügyi szakmérnök és Mezőgazdasági termékminősítő szakmérnök szakoknak.

A Debreceni Egyetemen 2003. április 16. és 2011. július 24. között a Hankóczy Jenő Növénytermesztési-, Kertészeti és Élelmiszertudományi Doktori Iskola vezetöje volt. A Doktori Iskola élelmiszer tudományi programjában Élelmiszeranalitikai, Növényi termék minőségvizsgálati, továbbá Növényi termék feldolgozási tárgyakat oktatott. Kulcsszerepe volt a Debreceni Egyetemen egy új multidiszciplináris Táplálkozás- és Elelmiszertudományi Doktori Iskola megszervezésében és 2017-es sikeres akkreditációjában. Ennek az orvosi-, biológiai- és agrár tudományterületeket ötvöző Doktori Iskolának a törzstagjaként új tudományos minőségi szintre emelte a hazai szakterületi integrációt, a Debreceni Egyetemen adott egyedi lehetőségekre építve.

Jelenleg a Debreceni Egyetem Kerpely Kálmán Doktori Iskolájának oktatója, valamint témavezető a Szent István Egyetem Környezettudományi Doktori Iskolájában.

Kiemelkedő eredményt ért el az oktatói-kutatói utánpótlás nevelésben. A fokozatot szerzett $\mathrm{PhD}$ hallgatóinak száma 22. Jelenleg $1 \mathrm{PhD}$ hallgató témavezetője. Négy Bólyai ösztöndíjas kutató témavezetője volt. Rendszeresen részt vesz hazánk egyetemein a doktori fokozatszerzési cselekményekben, továbbá az MTA doktori értekezések bírálója és a bíráló bizottság tagja.

Folyamatos szakmai megújulását jellemzi, hogy ma a Táplálkozástudományi MSc képzést vezeti, amely a Mezőgazdaság-, Élelmiszertudományi és Környezetgazdálkodási Kar, valamint az Orvostudományi Kar közös képzése. 
Kiemelkedő részt vállalt az általa oktatott tantárgyak tartalmi fejlesztésében, melyet a sikeres akkreditációk mellett tankönyvek, szakkönyvek, egyetemi jegyzetek, tantárgyi tematikák és tantervek igazolnak.

Napjainkban Professzor emeritusként (2018-) és rektori biztosként változatlan energiával végzi a Táplálkozás- és Élelmiszertudományi Doktori Iskola személyi és tárgyi feltételeinek fejlesztését. Meghatározó központi személye a Debreceni Egyetem most induló Mádi Projektjének, amely a hazai minőségi borászat új szemléletủ tudományos igényü gyakorlatának megteremtését tủzte ki célul.

Nem lenne teljes a kép, ha nem esne szó Győri Zoltánról, az emberről. Nyílt, közvetlen személyiségủ ember, akihez bármilyen beosztású kollégája vagy tanácsot kereső ismerőse bizalommal fordulhat. Mint minden sikeres pálya során is jelentkező, a nehezebb időszakokhoz szükséges töretlen optimizmus jellemzi, amihez mindig erőt meríthetett szerető és támogató családja köréből.

Születésnapja alkalmából a szakmai közösség, a barátok, a tisztelők, a tanítványok nevében töretlen lelkesedést, kitartást és minden jót kívánunk.

Tamás János 